\title{
Inverse background of Helicobacter pylori antibody and pepsinogen in reflux oesophagitis compared with gastric cancer: analysis of 5732 Japanese subjects
}

\author{
Y Yamaji, T Mitsushima, H Ikuma, M Okamoto, H Yoshida, T Kawabe, Y Shiratori,
} K Saito, K Yokouchi, M Omata

\begin{abstract}
Background-The relationship between Helicobacter pylori and reflux oesophagitis remains controversial.

Aims-To evaluate the relationship between $H$ pylori and reflux oesophagitis in a large number of Japanese subjects.

Subjects-A total of 5732 consecutive Japanese subjects during a health screening were enrolled.

Methods-Gastrointestinal endoscopy was performed on all subjects. We simultaneously measured serum anti- $H$ pylori antibody and pepsinogen as markers of $H$ pylori infection together with gastric atrophy. The risk of reflux oesophagitis was evaluated in relation to these markers, and the results were compared with those of gastric cancer.

Results-Reflux oesophagitis was found in 108 subjects. Both positivity for $H$ pylori antibody (adjusted odds ratio (OR) 0.67 (95\% confidence interval $0.45-1.0)$ ) and "low" pepsinogen indicating gastric atrophy (OR $0.35(0.18-0.68)$ ) were negatively associated with reflux oesophagitis. After subjects were classified into four groups based on positivity or negativity for $H$ pylori antibody and "low" pepsinogen, the prevalence of reflux oesophagitis showed a decreasing trend as $H$ pylori induced gastric atrophy became more severe. The risk of gastric cancer showed an increasing trend, exactly the opposite to that of reflux oesophagitis.
\end{abstract}

Conclusions-Analysis of a large series of Japanese subjects revealed a decreasing prevalence of reflux oesophagitis in conjunction with progress of gastric atrophy induced by $H$ pylori infection. This pattern was completely opposite to that of gastric cancer cases. A protective role of $\boldsymbol{H}$ pylori for reflux oesophagitis through the development of gastric atrophy has been suggested.

(Gut 2001;49:335-340)

Keywords: Helicobacter pylori; oesophagitis; gastro-oesophageal reflux disease; atrophic gastritis; gastric cancer

Although Helicobacter pylori has generally been accepted as a pathogen in gastritis, peptic ulcers, gastric cancer, and mucosa associated lymphoid tissue lymphoma, ${ }^{1-4}$ little is known about the relationship between $H$ pylori and reflux oesophagitis. Until recently there were only a small number of studies, and most could find no relationship..$^{5-8-11}$ In more recent years, several reports have suggested a protective role of $H$ pylori on reflux oesophagitis. ${ }^{12-14}$ It has previously been reported that reflux oesophagitis may develop in duodenal ulcer patients after eradication of $H$ pylori ${ }^{1215}{ }^{16}$ but subsequent studies reported conflicting results. ${ }^{17}{ }^{18}$ Gastric atrophy has been suggested to be an important modifying factor for the relationship between $H$ pylori and reflux oesophagitis. ${ }^{12}{ }^{14}$ Several investigators have also pointed to specific strains of $H$ pylori as being more protective for gastro-oesophageal reflux disease (GORD).$^{13}{ }^{20}$ In Western countries, a decrease in the incidence of peptic ulcer and gastric cancer but a remarkable increase in GORD and adenocarcinoma of the oesophagus or cardia $^{21-24}$ have been reported. The decline in $H$ pylori infection in these countries has been suggested to be involved in this phenomenon. ${ }^{19-21}$

The aim of this study was to evaluate the relationship between $H$ pylori infection and reflux oesophagitis in a large number of Japanese subjects undergoing medical check ups during a general health screening. This group was considered to be a cross sectional representation of the general Japanese population. We evaluated the background gastric mucosa of reflux oesophagitis cases on the basis of serum $H$ pylori antibody and pepsinogen as markers of $H$ pylori infection and gastric atrophy. ${ }^{25-27}$ All 5732 subjects underwent endoscopy and measurement of serum markers. The results of the reflux oesophagitis cases were then compared with those of gastric cancer, the association of which with $H$ pylori infection has already been established. ${ }^{3}$

\section{Methods}

SUBJECTS

A total of 6489 subjects who received medical check ups, including upper endoscopy, during a regular health screening programme at Kameda General Hospital and Makuhari Clinic were consecutively examined between February 1996 and February 1997. In Japan, these health programmes for healthy individuals are performed in an effort to detect diseases

Abbreviations used in this paper: GORD, gastro-oesophageal reflux disease; OR, odds ratio. 
at an early stage. Patients with specific symptoms requiring prompt medical attention were excluded. As part of their examination, subjects underwent a variety of procedures on one occasion, including physical examination, chest $x$ ray, electrocardiogram, blood laboratory tests, urinalysis, faecal occult blood test, and endoscopy.

After the examination we excluded subjects with peptic ulcers or a history of resected stomach because we considered the possibility of modification to endoscopic findings, $\mathrm{H}$ pylori status, or pepsinogen levels as a consequence of medication or impaired gastroduodenal function. We also excluded cases of active peptic ulcers and those patients with ulcer scars suggesting healed past ulcers. This excluded group was then evaluated separately.

The protocol was approved by the ethics committees of the respective institutions, and informed consent was obtained from each subject according to the Declaration of Helsinki.

\section{ENDOSCOPY AND CLINICOPATHOLOGICAL}

CLASSIFICATION

Gastrointestinal endoscopy was performed using electrical panendoscopes (types XQ200 or P230, Olympus, Tokyo, Japan). The bulbar portion of the duodenum, and the entire stomach and oesophagus were carefully observed.

Reflux oesophagitis was defined as visible erosions or ulcerations extending from the gastro-oesophageal mucosal junction, and was classified endoscopically according to the grading system of Savary and Miller. ${ }^{28}$

Histopathological assessment of gastric cancer was conducted using samples resected by surgical operation or endoscopy. Gastric cancer cases were classified as intestinal or diffuse in pathology using Lauren's classification. ${ }^{29}$ They were classified as cardiac or non-cardiac in terms of location.

SERUM H PYLORI ANTIBODY

Serum anti-H pylori IgG antibody was measured using a commercial ELISA kit (GAP-IgG kit; Biomerica INC., California, USA). Seropositivity for $H$ pylori antibody was defined by optical density values according to the manufacturer's protocol, and sensitivity and specificity were reported to be $95 \%$ and $83 \%$, respectively, compared with results by specific culture.

SERUM PEPSINOGEN LEVEL

Serum pepsinogen was measured using a commercial RIA kit (Pepsinogen I/II RIA BEAD Kit; Dainabot Co., Tokyo, Japan) and served as a marker of gastric atrophy. ${ }^{26} 27$ 30-33 $^{3}$ It was defined as "low" pepsinogen, possibly indicating gastric atrophy, when the criteria of both serum pepsinogen I level $\leqslant 70 \mathrm{ng} / \mathrm{ml}$ and pepsinogen I/II ratio (serum pepsinogen I (ng/ $\mathrm{ml}) /$ pepsinogen II $(\mathrm{ng} / \mathrm{ml})) \leqslant 3.0$ were simultaneously fulfilled, as proposed by Miki and colleagues. ${ }^{35}$ This has been widely applied to mass screening for gastric cancer in Japan on the basis of the hypothesis that atrophic gastritis is a major risk factor for gastric cancer. ${ }^{3} 336$ A sensitivity of $70.5 \%$ and specificity of $97.0 \%$ for atrophic gastritis compared with histology have been reported in Japan..$^{35}$

STATISTICAL METHODS

We used SAS software (SAS Institute Inc., North Carolina, USA) for statistical analysis. ANOVA with the Scheffé test was used for intergroup comparisons of mean ages and serum pepsinogen levels. Male to female rates were compared among groups using the $\chi^{2}$ test. Odds ratios (OR) with $95 \%$ confidence intervals (CI) were used as a measure of association, and adjusted for sex and age by unconditional logistic regression models. A two sided $\mathrm{p}$ value of less than 0.05 was considered statistically significant.

\section{Results}

THE STUDY POPULATION

A total of 6489 Japanese subjects (4319 men and 2170 women, mean age 48.1 years) were examined. Of them, 255 cases with active peptic ulcers (159 gastric ulcers and 108 duodenal ulcers, including 12 with both), 465 with peptic ulcer scars (254 gastric ulcers and 261 duodenal ulcers including 50 with both), and 37 with a resected stomach were excluded from the following analysis.

Hence 5732 subjects ( 3732 men and 2000 women) were analysed. Mean (SD) age was 48.1 (8.8) years; 905 were $<40,2526$ were $40-49,1685$ were $50-59$, and 616 were $\geqslant 60$ years old. None of the study subjects had been prescribed proton pump inhibitors, $\mathrm{H}_{2}$ blockers, or non-steroidal anti-inflammatory drugs within one month prior to the examination. Furthermore, none had undergone eradication therapy for $H$ pylori.

\section{REFLUX OESOPHAGITIS AND GASTRIC CANCER} CASES

Among the 5732 subjects, 108 cases (93 men and 15 women) of reflux oesophagitis $(1.9 \%)$ and 26 cases ( 25 men and one woman) of gastric cancer $(0.5 \%)$ were detected. The prevalence of reflux oesophagitis was $1.0 \%$ (9/905), $2.2 \%$ (59/2526), $1.8 \%$ (30/1685), and $1.6 \%$ $(10 / 616)$ at ages $<40,40-49,50-59$, and $\geqslant 60$ years, respectively. The prevalence of gastric cancer was $0.22 \%$ (2/905), $0.12 \%$ (3/2526), $0.65 \%(11 / 1685)$, and $1.6 \%(10 / 616)$ at ages $<40,40-49,50-59$, and $\geqslant 60$ years, respectively.

The grade of reflux oesophagitis was categorised as mild (stage I or II) according to Savary and Miller's classification in all cases. Histopathological features of gastric cancer were considered intestinal in 20 and diffuse in six cases. The gastric cardia was involved in three cases.

\section{SERUM H PYLORI ANTIBODY}

Among the 5732 subjects, 2695 (47.0\%) tested positive for the $H$ pylori antibody. The prevalence of seropositivity increased with age, from $34.5 \%$ (313/905), 44.6\% (1127/2526), $52.4 \%(883 / 1685)$, to $60.4 \%(372 / 616)$ at ages $<40,40-49,50-59$, and $\geqslant 60$ years, respectively. 
Table 1 Association of serum Helicobacter pylori antibody and serum pepsinogen status with reflux oesophagitis or gastric cancer among all subjects

\begin{tabular}{|c|c|c|c|c|c|c|c|c|c|}
\hline & \multirow[b]{2}{*}{ Total } & \multicolumn{2}{|c|}{ H pylori antibody } & \multirow[b]{2}{*}{ OR $(95 \% C I)$} & \multirow[b]{2}{*}{$p$ Value } & \multicolumn{2}{|c|}{ Pepsinogen level } & \multirow[b]{2}{*}{ OR $(95 \% C I)$} & \multirow[b]{2}{*}{$p$ Value } \\
\hline & & $(+)$ & $(-)$ & & & Low & Normal & & \\
\hline Total subjects & 5732 & 2695 & 3037 & 1.0 & - & 1218 & 4514 & 1.0 & - \\
\hline Reflux oesophagitis & 108 & 41 & 67 & $0.67(0.45-1.0)$ & 0.05 & 10 & 98 & $0.35(0.18-0.68)$ & $<0.01$ \\
\hline Gastric cancer & 26 & 17 & 9 & $1.7(0.74-3.8)$ & 0.21 & 16 & 10 & $4.2(1.8-9.6)$ & $<0.01$ \\
\hline
\end{tabular}

$\mathrm{OR}$, odds ratio of serum $H$ pylori antibody and serum pepsinogen status adjusted for sex and age using unconditional logistic regression models with $95 \%$ confidence intervals (CI).

Of the 108 cases of reflux oesophagitis, 41 were positive for $H$ pylori antibody. The prevalence of reflux oesophagitis in the $H$ pylori antibody $(+)$ and $(-)$ groups was $1.5 \%(41 / 2695)$ and $2.2 \%(67 / 3037)$, respectively (table 1$)$. OR adjusted for sex and age $(95 \% \mathrm{CI})$ was 0.67 $(0.45-1.0 ; \mathrm{p}=0.05)$, showing a negative correlation between $H$ pylori antibody and reflux oesophagitis.

Seventeen of the 26 gastric cancer cases were positive for $H$ pylori antibody. The prevalence of gastric cancer in the $H$ pylori antibody (+) and (-) groups was $0.63 \%(17 / 2695)$ and $0.3 \%(9 / 3037)$, respectively (table 1$)$. Adjusted OR (95\% CI) was $1.7(0.74-3.8 ; \mathrm{p}=0.21)$, showing no significant correlation.

\section{SERUM PEPSINOGEN LEVEI}

Among the total number of subjects, 1218 $(21.2 \%)$ were classified as "low" pepsinogen. The prevalence of "low" pepsinogen increased with age, from $9.6 \%(87 / 905), 16.9 \%(426 /$ $2526), 27.2 \%$ (459/1685), to $40.0 \%(246 / 616)$

Table 2 Characteristics of the four groups categorised by positivity or negativity for serum Helicobacter pylori antibody and gastric atrophy determined by serum pepsinogen level

\begin{tabular}{|c|c|c|c|c|c|c|c|c|}
\hline Group & $\begin{array}{l}\text { H pylori } \\
\text { antibody }\end{array}$ & Pepsinogen & $n$ & Male & Female & $\begin{array}{l}A g e^{\star \star} \\
(\text { mean }(S D))\end{array}$ & $\begin{array}{l}P G I^{\star *} \\
(\text { mean }(S D))\end{array}$ & $\begin{array}{l}P G I / I I^{\star *} \\
(\text { mean }(S D))\end{array}$ \\
\hline A & - & & 2703 & 1767 & 936 & 4 & 53 & .8) \\
\hline B & + & Normal & 1811 & 1191 & 620 & 48 & 72.5 & 4.2 \\
\hline C & + & Low & 884 & 541 & 343 & $51.7(8.8)$ & $41.7(17.2)$ & $2.0(0.7)$ \\
\hline D & - & Low & 334 & 233 & 101 & $52.3(9.6)$ & $35.4(18.5)$ & $1.9(0.7)$ \\
\hline
\end{tabular}

PG I, serum pepsinogen I level (ng/ml); PG I/II, pepsinogen I/II ratio, serum pepsinogen I $(\mathrm{ng} / \mathrm{ml}) /$ pepsinogen II $(\mathrm{ng} / \mathrm{ml})$.

${ }^{\star} \mathrm{p}<0.05$ by $\chi^{2}$ test; ${ }^{\star \star} \mathrm{p}<0.01$ by ANOVA.

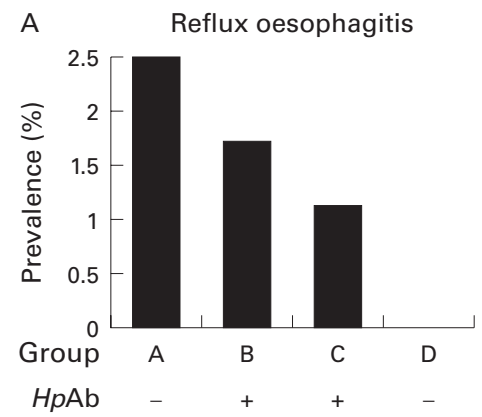

PG Normal Normal Low Low

$$
\begin{array}{ccccc}
\text { Cases } & 67 & 31 & 10 & 0 \\
\text { Total } & 2703 & 1811 & 884 & 334 \\
& \text { OR }(95 \% \mathrm{Cl})=0.58(0.44-0.76) \\
\mathrm{p}<0.0001
\end{array}
$$
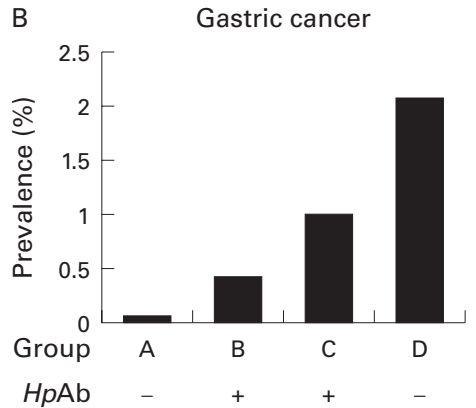

PG Normal Normal Low Low

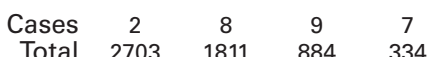

OR $(95 \% \mathrm{Cl})=2.3(1.5-3.4)$

$\mathrm{p}<0.0001$
Figure 1 Prevalence of reflux oesophagitis in all subjects in each group, categorised by serum Helicobacter pylori antibody $(H p A b)$ and pepsinogen level (PG), showed a gradually decreasing trend in the order of group $A$ to group $D(A)$, the exact opposite to the pattern presented by the increasing trend of gastric cancer (B). The odds ratios with $95 \%$ confidence intervals (OR (95\% CI)) between adjacent groups, which may reflect the progress of gastric atrophy induced by $H$ pylori infection, adjusted for sex and age using unconditional logistic regression models, were $0.58(0.44-0.76 ; p<0.0001)$ for reflux oesophagitis and $2.3(1.5-3.4 ; p<0.0001)$ for gastric cancer. at ages $<40,40-49,50-59$, and $\geqslant 60$ years, respectively.

Ten of the reflux oesophagitis cases were classified as "low" pepsinogen. The prevalence rates of reflux oesophagitis in the "low" pepsinogen and "normal" pepsinogen groups were $0.82 \%(10 / 1218)$ and $2.2 \%$ (98/4514), respectively (table 1). Adjusted OR (95\% CI) was $0.35(0.18-0.68 ; \mathrm{p}<0.01)$, exhibiting a negative correlation between serum pepsinogen level and reflux oesophagitis.

Sixteen of the 26 cases of gastric cancer were classified as "low" pepsinogen. The prevalence rates of gastric cancer in the "low" pepsinogen and "normal" pepsinogen groups were $1.3 \%$ (16/1218) and $0.22 \%(10 / 4514)$, respectively (table 1). Adjusted OR (95\% CI) was 4.2 (1.8$9.6 ; \mathrm{p}<0.01)$, showing a distinct positive correlation.

ANALYSIS OF THE BACKGROUND OF REFLUX OESOPHAGITIS AND GASTRIC CANCER BY COMBINATION ANALYSIS OF SERUM H PYLORI ANTIBODY AND PEPSINOGEN

Subjects were classified into four groups according to positivity and negativity for $H$ pylori antibody and gastric atrophy determined by pepsinogen: group A (H pylori antibody (-) and "normal" pepsinogen), group B (H pylori antibody (+) and "normal" pepsinogen), group C (H pylori antibody (+) and "low" pepsinogen), and group D (H pylori antibody $(-)$ and "low" pepsinogen). Of the total 5732 subjects, $2703(47.1 \%)$ were allocated to group A, 1811 (31.6\%) to group B, $884(15.4 \%)$ to group C, and $334(5.8 \%)$ to group D.

The clinical features of these groups are shown in table 2. Group C showed a significantly lower male/female ratio than the other groups ( $\mathrm{p}<0.05$ by $\chi^{2}$ test). Mean ages in groups A to D tended to increase. Serum pepsinogen I level was highest in group B followed by group A, group C, and group D. Serum pepsinogen $\mathrm{I} / \mathrm{II}$ ratio decreased from group $\mathrm{A}$ to group D. Differences in these parameters among groups were all significant $(p<0.01$ by ANOVA).

In the 108 cases of reflux oesophagitis, 67 were classified as group A, 31 as group B, 10 as group $\mathrm{C}$, and 0 as group $\mathrm{D}$ (fig $1 \mathrm{~A}$ ). Of the 26 cancer cases, two (including one cardiac cancer) were classified as group A, eight as group $\mathrm{B}$, nine as group $\mathrm{C}$, and seven (including two cardiac cancers) as group D (fig 1B).

As shown in fig 1, the prevalence of reflux oesophagitis among all subjects in each group showed a gradually decreasing trend in the order of groups A to D, a pattern opposite to that of gastric cancer. In reflux oesophagitis 
Table 3 Prevalence (\%) of reflux oesophagitis and gastric cancer in subjects aged $<50$ or $\geqslant 50$ years old

\begin{tabular}{|c|c|c|c|c|}
\hline $\begin{array}{l}\text { Group } \\
\text { H pylori antibody } \\
\text { Pepsinogen }\end{array}$ & $\begin{array}{l}\text { A } \\
- \\
\text { Normal }\end{array}$ & $\begin{array}{l}\text { B } \\
+ \\
\text { Normal }\end{array}$ & $\begin{array}{l}C \\
+ \\
\text { Low }\end{array}$ & $\begin{array}{l}D \\
- \\
\text { Low }\end{array}$ \\
\hline \multicolumn{5}{|c|}{ Reflux oesophagitis } \\
\hline$<50 \mathrm{y}$ & 2.3 & 1.9 & 1.3 & 0 \\
\hline$\geqslant 50 \mathrm{y}$ & 2.9 & 1.5 & 1.0 & 0 \\
\hline \multicolumn{5}{|l|}{ Gastric cancer } \\
\hline$<50 y$ & 0 & 0 & 0.8 & 1.6 \\
\hline$\geqslant 50 \mathrm{y}$ & 0.2 & 1.1 & 1.2 & 2.4 \\
\hline
\end{tabular}

cases, the $H$ pylori antibody (-) and "normal" pepsinogen group showed the highest risk $(2.5 \%, 67 / 2703)$ among the four groups, the $H$ pylori antibody (+) and "normal" pepsinogen the second highest $(1.7 \%, 31 / 1811)$, the $H$ pylori antibody (+) and "low" pepsinogen the third highest $(1.1 \%, 10 / 884)$, and the $H$ pylori antibody (-) and "low" pepsinogen the lowest risk $(0 \%, 0 / 334)$ (fig $1 \mathrm{~A})$. The order was the exact reverse in the gastric cancer cases, with prevalence rates in each group of $0.07 \%$ (2/2703), $0.44 \%(8 / 1811), 1.0 \%(9 / 884)$, and $2.1 \%$ (7/334), respectively (fig $1 \mathrm{~B}$ ).

Adjusted ORs (95\% CI) between adjacent groups were $0.58(0.44-0.76 ; \mathrm{p}<0.0001)$ for reflux oesophagitis, revealing a clearly negative correlation, and $2.3(1.5-3.4 ; \mathrm{p}<0.0001)$ for gastric cancer, a distinctly positive correlation. To incorporate the parameter of "group" classification into logistic regression models, the serial values of one, two, three, and four were assigned to groups $\mathrm{A}, \mathrm{B}, \mathrm{C}$, and $\mathrm{D}$, respectively, on the assumption that the association exists in this order. The association with both reflux oesophagitis and gastric cancer was stronger than any other manner of assignment (data not shown).

For fear that the parameter of age in particular might be confounding, the analysis was also performed separately for those $<50$ and those $\geqslant 50$ years old. Similar results were obtained in both analyses (table 3 ).

ANALYSIS OF THE EXCLUDED POPULATION

In the 757 subjects with peptic ulcers, ulcer scars, or resected stomach who were excluded from the analysis, $187(24.7 \%)$ were classified as group A, $421(55.6 \%)$ as group B, 118 $(15.6 \%)$ as group C, and $31(4.1 \%)$ as group D. The proportion of group B was relatively higher than group A compared with the included population. However, if these subjects had been included, similar results would have been obtained in terms of reflux oesophagitis and gastric cancer (data not shown).

\section{Discussion}

Increasing attention has been paid to the relationship between $H$ pylori infection and reflux oesophagitis in recent years. The pathogenic role of $H$ pylori in reflux oesophagitis was suspected in earlier studies ${ }^{37} 38$ while most other studies found no relationship. ${ }^{5-11}$ In contrast, the possible protective role of $H$ pylori in reflux oesophagitis and other GORD related diseases such as Barrett's oesophagus and oesophageal adenocarcinoma has recently been suggested. ${ }^{12-1420}$
Labenz et al demonstrated the development of reflux oesophagitis in patients with duodenal ulcers after $H$ pylori eradication. ${ }^{12}$ However, the latest studies have not always supported these results. ${ }^{17} 18$

It is clear from this plethora of conflicting evidence that the association between reflux oesophagitis and $H$ pylori has yet to be conclusively established, and studies based on large population samples have been conspicuous by their absence. The aim of the present investigation was to shed a definitive light on this problem using a large study population, and to use endoscopic procedures to obtain confirmatory results of reflux oesophagitis.

$H$ pylori is known to evoke gastritis, and chronic gastritis is thought to induce the development of gastric atrophy, metaplasia, and finally cancer. ${ }^{3336}$ Pepsinogen I and II, two main precursors of pepsin, are both produced by the chief and mucous neck cells of the stomach, and were measured as markers of gastric atrophy. Pepsinogen II is also produced by pyloric glands. In mild gastritis, serum pepsinogen I and II levels increase due to inflammation. The increase in pepsinogen II is more prominent, leading to a decrease in the pepsinogen I/II ratio. As chronic gastritis leads to the development of gastric atrophy, the pepsinogen I level specifically decreases due to replacement of chief cells by pyloric glands, and consequently the pepsinogen I/II ratio decreases further. Hence both low serum pepsinogen I level and low pepsinogen I/II ratio are known to be specific markers of gastric atrophy. ${ }^{26} 27$ 30-33 In the present study, we attempted to evaluate the status of serum $H$ pylori antibody and pepsinogen in patients with reflux oesophagitis, and carried out a comparison with gastric cancer cases.

Our results suggested a negative correlation between reflux oesophagitis and gastric atrophy induced by $H$ pylori infection in terms of the status of serum $H$ pylori antibody and the level of pepsinogen, in contrast with the positive correlation with gastric cancer. However, both reflux oesophagitis and gastric cancer showed only weak association with $H$ pylori antibody which may be explained by the contradictory result that $H$ pylori antibody negative subjects included both the highest and lowest risk groups in relation to reflux oesophagitis and gastric cancer.

In this study, group $\mathrm{D}$ (H pylori antibody (-) and low pepsinogen) showed the lowest risk of reflux oesophagitis and the highest risk of gastric cancer. This is an apparently confusing result if gastric cancer is positively associated with $H$ pylori infection. ${ }^{33}{ }^{36}$ Except for group $\mathrm{D}$, groups $\mathrm{A}-\mathrm{C}$ corresponded to the stages of progressive gastric atrophy induced by chronic infection of $H$ pylori, in which those without $H$ pylori infection or gastric atrophy (group A) are infected with $H$ pylori (group B), and then develop gastric atrophy (group C). Therefore, the characteristics of the $H$ pylori antibody $(-)$ and "low" pepsinogen group must be evaluated to ascertain that there exists a previously established association between $H$ pylori and gastric cancer. $^{33336}$ 
Group D showed the lowest level of pepsinogen I and pepsinogen I/II ratio among the four groups. Previous studies revealed that declines in both pepsinogen I level and pepsinogen I/II ratio were proportional to the extent of gastric atrophy and decrease in acid output. ${ }^{26}{ }^{27-30} \mathrm{It}$ has also been suggested that $H$ pylori antibody titre might decrease with progression of gastric mucosal atrophy. ${ }^{39-42} \mathrm{~A}$ recent study revealed that in patients with low serum pepsinogen level and histologically confirmed gastric atrophy, $H$ pylori antibody titres declined during the mean follow up of 10 years, and some cases actually became negative. ${ }^{43}$ In our unpublished data, many Japanese patients with chronic atrophic gastritis and negative $H$ pylori antibody were finally judged as false negative by the more sensitive gastric juice polymerase chain reaction method. ${ }^{44-46}$ On the basis of these findings, it is tempting to speculate that this $H$ pylori antibody (-) and "low" pepsinogen group simply has a considerably reduced titre of $H$ pylori antibody due to the greatly extended gastric atrophy, and this interpretation could well explain the highest risk for gastric cancer in this group. Thus groups A-D reflect the progress of gastric atrophy induced by $H$ pylori in this order. Taken together, our results suggest that the extent of $H$ pylori induced gastric atrophy is proportionally associated negatively with reflux oesophagitis and positively with gastric cancer, independent of sex or age.

$H$ pylori has been thought to play both pathogenic and protective roles in reflux oesophagitis. ${ }^{147}$ Increased gastric acid output (as in duodenal ulcer cases) ${ }^{48}$ and mucosal injury by various cytotoxins due to $H$ pylori infection ${ }^{49}$ have been hypothesised as pathogenic mechanisms for reflux oesophagitis. On the other hand, decreased acid output due to extended gastric atrophy ${ }^{50}{ }^{51}$ and acid neutralising effects of ammonia production by $\mathrm{H}_{\text {pylori }} \mathrm{i}^{52}$ were reported to inhibit the development of reflux oesophagitis. Our results are not only consistent with the generally accepted notion that $H$ pylori induces gastric cancer through gastric atrophy ${ }^{33} 36$ but also support the concept that low acid output due to gastric atrophy plays a protective role in reflux oesophagitis. ${ }^{12-14}$

The difference in the distribution of $H$ pylori strains between Japan and Western countries could have influenced our results. The CagA positive strain, which is considered more pathogenic for atrophic gastritis, ${ }^{53}$ peptic ulcers, ${ }^{54}$ and gastric cancer, ${ }^{55}$ was suggested to play a protective role in GORD. ${ }^{13}{ }^{20}$ Vicari et al reported that CagA positive strains decreased in severe complications of GORD such as Barrett's oesophagus and Barrett's dysplasia. ${ }^{13}$ As we have previously shown, most of the $H$ pylori strains in Japan are CagA positive. ${ }^{56} 57$ Therefore, our results may specifically indicate an effect of CagA positive $H$ pylori strain. In Western countries, the CagA status of $H$ pylori strains may be strongly related to outcome. $^{131920}$

In conclusion, we have shown a gradually decreasing risk of reflux oesophagitis according to the progress of gastric atrophy induced by $H$ pylori infection using a large number of Japanese subjects. This pattern contrasted with that of patients with gastric cancer. This result may suggest a protective role of $H$ pylori for reflux oesophagitis, and it may be consistent with epidemiological data from Western countries which show an increase in GORD ${ }^{21-24}$ and a decrease in gastric cancer ${ }^{21}{ }^{22}$ in concert with the decline in $H$ pylori infection. ${ }^{19-21}$

1 Kuipers EJ, Uyterlinde AM, Pena AS, et al. Long-term sequelae of Helicobacter pylori gastritis. Lancet 1995;345:1525-8

2 NIH Consensus Development Panel on Helicobacter pylori in Peptic Ulcer Disease. NIH Consensus Conference. Helicobacter pylori in peptic ulcer disease. $7 \mathrm{Am} \mathrm{Med} \mathrm{Assoc}$ 1994;272:65-9.

3 Infection with Helicobacter pylori. IARC Monographs on the Evaluation of Carcinogenic Risks to Humans 1994;61:177240.

4 Stolte M. Helicobacter pylori gastritis and gastric MALTlymphoma. Lancet 1992;339:745-6.

5 Cheng EH, Bermanski P, Silversmith M, et al. Prevalence of Campylobacter pylori in esophagitis, gastritis, and duodenal disease. Arch Intern Med 1989;149:1373-5.

6 Befrits R, Granstrom M, Rylander M, et al. Helicobacter pylori in 205 consecutive endoscopy patients. Scand F Infect Dis 1993;25:185-91.

7 Rosioru C, Glassman MS, Halata MS, et al. Esophagitis and Helicobacter pylori in children: incidence and therapeutic implications. Am f Gastroenterol 1993;88:510-13.

8 O'Connor HJ, Cunnane K. Helicobacter pylori and gastrooesophageal reflux disease-a prospective study. Ir $7 \mathrm{Med}$ Sci 1994;163:369-73.

9 Liston R, Pitt MA, Banerjee AK. Reflux oesophagitis and Helicobacter pylori infection in elderly patients. Postgrad Med f 1996;72:221-3.

10 Newton M, Bryan R, Burnham WR, et al. Evaluation of Helicobacter pylori in reflux oesophagitis and Barrett's oesophagus. Gut 1997;40:9-13.

11 Werdmuller BF, Loffeld RJ. Helicobacter pylori infection has no role in the pathogenesis of reflux esophagitis. Dig Dis Sci 1997;42:103-5.

12 Labenz J, Blum AL, Bayerdorffer E, et al. Curing Helicobacter pylori infection in patients with duodenal ulcer may provoke reflux esophagitis. Gastroenterology 1997;112:1442-7.

13 Vicari JJ, Peek RM, Falk GW, et al. The seroprevalence of cagA-positive Helicobacter pylori strains in the spectrum of gastroesophageal reflux disease. Gastroenterology 1998;115: $50-7$

$14 \mathrm{Xia} \mathrm{HH}$, Talley NJ. Helicobacter pylori infection, reflux esophagitis, and atrophic gastritis: an unexplored triangle. Am $\mathcal{F}$ Gastroenterol 1998;93:394-400.

15 Michopoulos S, Tsibouris P, Balta A, et al. Clinical spectrum of gastroesophageal reflux disease after HP eradication in patients with duodenal ulcer. Gastroenterology 1998;114:A227.

16 Di-Mario F, Dal-Bo N, Saladin S, et al. The appearance of GORD in patients with duodenal ulcer after eradication of Helicobacter pylori $(\mathrm{Hp})$ infection: A 4 year prospective Helicobacter pylori (Hp) infection: A

17 O'Connor HJ, McGee C, Mehana N, et al. Prevalence of gastroesophageal reflux disease (GERD) in $H$. pylori-
positive peptic ulcer disease and the impact of eradication positive peptic ulcer disease and the impact
therapy. Gastroenterology 1998;114:A244.

18 Bretagne JF, Barthelemy P, Caekaert A. Are gastroesophageal reflux disease (GERD) and peptic esophagitis (PE) a complication of the eradication of Helicobacter pylori $(\mathrm{Hp})$ in patients with duodenal ulcer? Gastroenterology 1998;114: A81.

19 Blaser MJ. Not all Helicobacter pylori strains are created equal: should all be eliminated? Lancet 1997;349:1020-2.

20 Chow WH, Blaser MJ, Blot WJ, et al. An inverse relation between cagA+ strains of Helicobacter pylori infection and risk of esophageal and gastric cardia adenocarcinoma. Cancer Res 1998;58:588-90.

21 el-Serag HB, Sonnenberg A. Opposing time trends of peptic ulcer and reflux disease. Gut 1998;43:327-33.

22 Blaser MJ. Helicobacter pylori infection and adenocarcinoma of distal stomach. Eur $\mathcal{f}$ Gastroenterol Hepatol 1993;5(suppl 1):99-102.

23 Blot WJ, Devesa SS, Kneller RW, et al. Rising incidence of adenocarcinoma of the esophagus and gastric cardia. FAMA 1991;265:1287-9.

24 Pera M, Cameron AJ, Trastek VF, et al. Increasing incidence of adenocarcinoma of the esophagus and esophagogastric unction. Gastroenterology 1993;104:510-13.

25 The EUROGAST Study Group. An international association between Helicobacter pylori infection and gastric cancer. Lancet 1993;341:1359-62.

26 Samloff IM, Varis K, Ihamaki T, et al. Relationships among serum pepsinogen I, serum pepsinogen II, and gastric mucosal histology. A study in relatives of patients with pernicious anemia. Gastroenterology 1982;83:204-9.

27 Miki K, Ichinose M, Shimizu A, et al. Serum pepsinogens as screening test of extensive chronic gastritis. Gastroenterol fpn 1987;22:133-41. 
28 Savary M, Miller G. The esophagus: Handbook and atlas of endoscopy. Solothurn, Switzerland: Gassmann, 1987.

29 Lauren P. The two histological main types of gastric carcinoma: diffuse and so-called intestinal-type carcinoma. Acta Pathol Microbiol Scand 1965;64:31-9.

30 Samloff IM, Varis K, Ihamaki T, et al. Serum pepsinogens and II and gastric acid output: effect of gastritis. Prog Clin Biol Res 1985;173:129-38.

31 Westerveld BD, Pals G, Lamers CB, et al. Clinical significance of pepsinogen A isozymogens, serum pepsinogen $\mathrm{A}$ and $\mathrm{C}$ levels, and serum gastrin levels. Cancer 1987; 59:952-8.

32 Kekki M, Samloff IM, Varis K, et al. Serum pepsinogen I and serum gastrin in the screening of severe atrophic corpus gastritis. Scand f Gastroenterol Suppl 1991;186:109 16.

33 Webb PM, Hengels KJ, Moller H, et al. The epidemiology of low serum pepsinogen A levels and an international association with gastric cancer rates. EUROGAST Study Group. ation with gastric cancer rates. EUR
Gastroenterology 1994;107:1335-44.

34 Miki K, Ichinose M, Kakei N, et al. The clinical application of the serum pepsinogen I and II levels as a mass screening method for gastric cancer. Adv Exp Med Biol 1995;362 139-43

35 Watanabe Y, Kurata JH, Mizuno S, et al. Helicobacter pylori infection and gastric cancer. A nested case-control study in a rural area of Japan. Dig Dis Sci 1997;42:1383-7.

36 Correa P. Human gastric carcinogenesis: a multistep and multifactorial process-First American Cancer Society Award Lecture on Cancer Epidemiology and Prevention. Cancer Res 1992;52:6735-40.

37 Borkent MV, Beker JA. Treatment of ulcerative reflux oesophagitis with colloidal bismuth subcitrate in combination with cimetidine Gut 1988;29:385-9.

38 Grebenev AL. Helicobacter pylori $(\mathrm{Hp})$ and reflux esophagitis. Am 7 Gastroenterol 1994;89:1372.

39 Karnes WE Jr, Samloff IM, Siurala M, et al. Positive serum antibody and negative tissue staining for Helicobacter pylori in subjects with atrophic body gastritis. Gastroenterolpylori in subjects with
ogy 1991;101:167-74

40 Forman D, Webb P, Parsonnet J. H pylori and gastric cancer. Lancet 1994;343:243-4.

41 Forman D. The prevalence of Helicobacter pylori infection in gastric cancer. Aliment Pharmacol Ther 1995;9:71-6.

42 Fukuda H, Saito D, Hayashi S, et al. Helicobacter pylori infection, serum pepsinogen level and gastric cancer: a case-control study in Japan. Fpn F Cancer Res 1995;86:6471 .

43 Kokkola A, Puolakkainen P, Rautelin H, et al. Time-course of $H$. pylori antibody titres in patients with atrophic corpus gastritis. Gut 1999;45(suppl 3):A54.
44 Shimada T, Ogura K, Ota S, et al. Identification of Helicobacter pylori in gastric specimens, gastric juice, saliva, and 列

45 Kawamata O, Yoshida H, Hirota K, et al. Nestedpolymerase chain reaction for the detection of Helicobacter pylori infection with novel primers designed by sequence analysis of urease A gene in clinically isolated bacterial strains. Biochem Biophys Res Commun 1996;219:266-72.

46 Yoshida H, Hirota K, Shiratori Y, et al. Use of a gastric juice-based PCR assay to detect Helicobacter pylori infection in culture-negative patients. F Clin Microbiol 1998;36: $317-20$

47 Vicari J, Falk GW, Richter JE. Helicobacter pylori and acid peptic disorders of the esophagus: is it conceivable? $A m \mathcal{F}$ Gastroenterol 1997;92:1097-102.

48 El-Omar EM, Penman ID, Ardill JE, et al. Helicobacter pylori infection and abnormalities of acid secretion in patients with duodenal ulcer disease. Gastroenterology 1995;109:681-91.

49 Tee W, Lambert JR, Dwyer B. Cytotoxin production by Helicobacter pylori from patients with upper gastro-

50 Feldman M, Cryer B, McArthur KE, et al. Effects of aging and gastritis on gastric acid and pepsin secretion in humans: a prospective study. Gastroenterology 1996;110: 1043-52

51 El-Omar EM, Oien K, El-Nujumi A, et al. Helicobacter pylori infection and chronic gastric acid hyposecretion. Gastroenterology 1997;113:15-24.

52 Verdu EF, Armstrong D, Sabovcikova L, et al. High concentrations of ammonia, but not volatile amines, in gastric uice of subjects with Helicobacter pylori infection. Helicobacter 1998;3:97-102.

53 Kuipers EJ, Perez-Perez GI, Meuwissen SG, et al. Helicobacter pylori and atrophic gastritis: importance of the cagA status. F Natl Cancer Inst 1995;87:1777-80.

54 Ching CK, Wong BCY, Kwok E, et al. Prevalence of Cag A-bearing Helicobacter pylori strains detected by the antiCag A assay in patients with peptic ulcer disease and in controls. Am $\mathcal{f}$ Gastroenterol 1996;91:949-53.

55 Blaser MJ Perez-Perez GI, Kleanthous $\mathrm{H}$, et al. Infection with Helicobacter pylori strains possessing cagA is associated with an increased risk of developing aden

56 Ogura K, Kanai F, Maeda S, et al. High prevalence of cytotoxin positive Helicobacter pylori in patients unrelated to the presence of peptic ulcers in Japan. Gut 1997;41:463-8.

57 Maeda S, Kanai F, Ogura K, et al. High seropositivity of anti-CagA antibody in Helicobacter pylori-infected patients irrelevant to peptic ulcers and normal mucosa in 